\title{
CERCARIAE FOUND IN THE REGION SOUTH-EAST OF AMSTERDAM
}

\author{
by \\ ELISABETH VAN DEN BROEK \& ARY C. BRUGGEMAN \\ Zoological Laboratory, University of Amsterdam, The Netherlands
}

\begin{abstract}
Cercariae have been collected and studied from two sampling areas, situated at a distance of about $5 \mathrm{~km}$ of one another, South-East of Amsterdam.

Thirteen species are mentioned in this paper, seven of which are reported from the Netherlands for the first time. Two species are described in detail: an echinostome cercaria tentatively identified as Cercaria deficipinnata Khan, 1960, and a new xiphidiocercaria belonging to the group "armatae", named Cercaria otiosa $\mathrm{n}$. sp.

The cercarial fauna in the two sampling areas is compared, and possible causes of differences are briefly discussed.
\end{abstract}

\section{INTRODUCTION}

Since many years, studies on trematode larvae and their life cycles have been carried out at the Zoological Laboratory of the University of Amsterdam. Several students, among whom Borgsteede in 1966 and Daalder in 1967, have compiled lists of cercarial species found by them in various waters around Amsterdam, but no survey has yet been published of the species found within this region, which is now rapidly changing because of manifold human activities. The composition of the cercarial fauna of a certain area depends on the presence of both final and intermediate hosts of the various species and will therefore vary both in time and in space.

During the summer seasons of the past three years, cercariae have been studied in two areas within $10 \mathrm{~km}$ South-East of Amsterdam. In the Bijlmermeer, a site where a suburb is being built, samples have been taken in 1973 by the junior author in a small pond and a shallow ditch. Since then, these waters have been filled up. Meanwhile, the senior author started an investigation of the trematode fauna of a larger water body known as the Diemerplassen, a study which was continued up to the autumn of 1975 . Because these two sampling areas were rather different in character, the combined results of our surveys present a more generalized picture of the composition of the cercarial fauna in this region, which might be compared later with that of other areas in the neighbourhood.

\section{MATERIAL AND METHODS}

Snails were taken to the laboratory, isolated in tubes and examined daily for the shedding of cercariae.

In the Bijlmermeer, most snails collected were lymnaeids, mainly Lymnaea peregra (Müller, 1774) forma ovata and Lymnaea stagnalis (Linnaeus, 1758), but also some prosobranchs, viz. Bithynia tentaculata (Linnaeus, 1758) were found. Collecting trips were made on 31 July and on 18 and 27 September 1973.

Along the shores of the Diemerplassen, collecting took place in several fixed sampling stations. Most snails found here were $B$. tentaculata. $L$. peregra being present only in a few stations, whereas $L$. stagnalis was very rare. Almost all infected snails from this area came from the Overdiemerplas which is warmed up by cooling water from an electric power station. Here, collecting was repeatedly done during the summer seasons of three successive years (1973, 1974, 1975). The snails collected here were killed within three weeks and examined for the presence of trematode larvae.

Cercariae were studied under cover glass in water or in a $0.7 \% \mathrm{NaCl}$ solution. If not stated otherwise, 20 heat-killed specimens of each species were measured under cover glass. The figures were prepared to scale by the junior author from freehand sketches. 
The key given by Nasir \& Erasmus (1964) has been very useful for a preliminary identification of the cercariae. Various forms of cercariae which could not be identified and of which no adequate description could be made, have not been enumerated in this paper.

\section{RESULTS}

Cercaria of Diplostomum spathaceum (Rudolphi, 1819)

The final host of this species, the Black-headed Gull (Larus ridibundus Linnaeus, 1766) is very common in and around Amsterdam. The furcocercariae were consequently found in all samples in the Bijlmermeer, in the Diemerplassen (1 October 1973, 17 June 1974) and also in a small pond in the Amsterdam Zoo (1973).

Morphology and dimensions of the cercariae were in complete agreement with the data provided by Meyer (1964). In all cases, the host was Lymnaea peregra.

Some observations were made concerning the biology of the cercariae. Under laboratory circumstances most cercariae emerged from the host between 1.00 and 4.00 p.m. (observations on 23 and 24 August 1973). They remained active for about 28 hours, the maximum life span being about 72 hours.

In the summer of 1974, 42 out of 61 fishes taken from the Diemerplassen had their eyes infected by larvae that were identified as $D$. spathaceum (E. E. A. Ooms, pers. comm.).

\section{Cercaria helvetica XV Dubois, 1929}

Apart from Dubois (1929) and Meyer (1964) no one has reported this furcocercaria, which might be confused with the previous one. We found it in all samples from the Bijlmermeer, once in the Diemerplassen (24 June 1975) and also in the pond in the Amsterdam Zoo. Hosts were Lymnaea peregra and $L$. stagnalis. The life cycle is not known.

Morphology and dimensions of our specimens were in agreement with the description given by Meyer (1964). A few additional remarks are sufficient to underline the differences between this species and the cercaria of $D$. spathaceum.

Anteriorly, two transversal rows of rather large, alternating spines are conspicuous. Then follow three rows of slightly smaller spines and six rows of small ones. Separate bands of double rows of spines, seven in number, are found on the forebody before the anterior margin of the ventral sucker.

The prepharynx is rather long, the oesophagus very short, whereas in $D$. spathaceum the oesophagus is longer than the pharynx. The diameter of the ventral sucker is about 1.3 times the length of the anterior organ. The four penetration glands, although in about the same position as in $D$. spathaceum, are larger than in this species.

The caudal bodies in the tail are clearly situated in two rows. In older specimens they break up into smaller fragments and the pattern is disrupted. They may almost have disappeared after 24 hours.

In one case, a snail infected with this species also harboured an infection with an unidentified xiphidiocercaria.

In the laboratory the emergence period and life span of $C$. helvetica $X V$ did not differ from those found in the cercaria of $D$. spathaceum. According to Meyer (1964) they also penetrate in fish and continue their life cycle in the eyes.

Cercaria of Apatemon (Australapatemon) minor Yamaguti, 1933

This furcocercaria was found twice in the Bijlmermeer ditches, in Lymnaea peregra.

The species has been adequately described by Meyer (1964) and our specimens agree with this description. In table I, dimensions taken from 20 specimens are compared with those given by Meyer (1964) and by Iles (1959), who studied the life cycle of the species.

We found three concentric rows of hooklets on the ventral sucker, Meyer (1964) mentions three rows as well, but Iles (1959) has observed four.

There are seven pairs of caudal bodies, but in older animals these often split up into smaller fragments.

Flame cell formula: $2[2+(2+2+(1))]=14$.

Honer (1963) gives an incomplete description of a cercaria called by him $A$. gracilis minor, which he found near Amsterdam. This form does not seem to be identical with our species.

\section{Cercaria cristata sensu lato}

This brevifurcate cercaria was found in the 
Table I. Measurements (in $\mu \mathrm{m}$ ) of the cercaria of Apatemon minor.

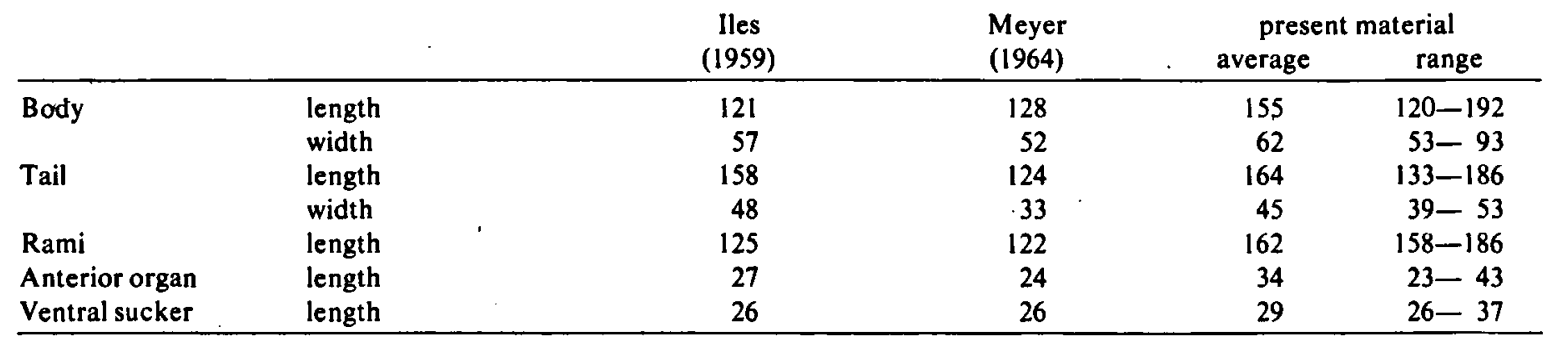

Diemerplassen on 1 July 1974 and on 24 June and 22 July 1975 in Lymnaea peregra. In 1967, Daalder (pers. comm.) had already found it in the Nieuwe Meer, South of Amsterdam, this being the first record for The Netherlands.

Our specimens differed from those described by Wesenberg-Lund (1934) in the position of the dorsal fin fold. In our specimens it reached from the posterior end of the penetration organ to about five sixth of the body length; in Wesenberg-Lund's specimens it reached almost to the attachment of the tail. However, the fin fold in our specimens is larger than that described by Dubois (1929) for his Cercaria helvetica $X V I$.

Cercaria of Paryphostomum radiatum (Dujardin, 1845)

This echinostome species appears to occur regularly in the Diemerplassen. It was collected on 1 October 1973, 5 and 26 August 1974 and 22 August 1975 from Lymnaea peregra.

Kiselienè (1971) has presented a description and a survey of the life cycle, in which Cercaria helvetica XXI Dubois, 1929, is accepted as being a synonym of this species. Her measurements are compared with ours in table II.

According to Kiselienè (1971), the collar spine formula is: $4+6+7+6+4=27$. In our specimens, we found four corner spines, a double dorsal row consisting of four oral and five aboral spines, the remaining five spines on each side being aboral lateral ones and the formula being: $4+5+9+5+4$ $=27$. This actually agrees with the drawing presented by Kiselienè (1971).

The flame cell formula is, according to Kiselienè (1971): $2[(3+3+3)+(3+3)]=30$. We were not able to determine the flame cell formula.

The cercaria emerges in the early morning hours, and at room temperature most specimens are no longer able to swim after 8 to 10 hours. They seem to be very sensitive to low temperatures: below $20^{\circ} \mathrm{C}$ they are immobilized within a few hours.

Kiselienè (1971) found the metacercariae in the preoral muscles and within the gills of young Carp, Cyprinus carpio Linnaeus, 1758. The adult occurs in the intestine of the Cormorant, Phalacrocorax carbo (Linnaeus, 1758). Cormorants, belonging to a colony at about $10 \mathrm{~km}$ distance, can be seen on the Diemerplassen fairly regularly.

\section{Cercaria cf. deficipinnata Khan, 1960}

(Fig. 1)

Three, clearly separate species of echinostome cercariae with 37 collar spines were found in the Bijlmermeer. Echinostome cercariae are very difficult to classify. Two species could not be related to already known forms, and because our

Table II. Measurements (in $\mu \mathrm{m}$ ) of the cercaria of Paryphostomum radiatum.

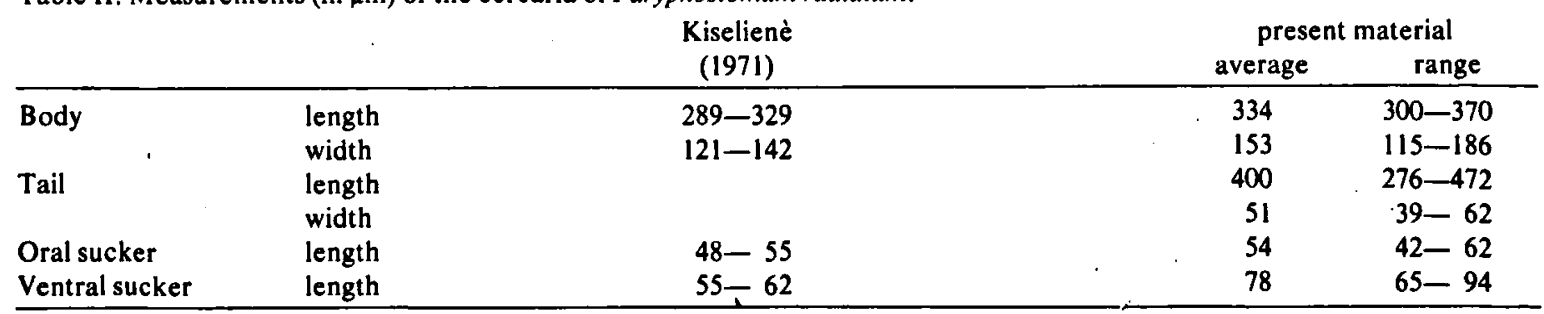




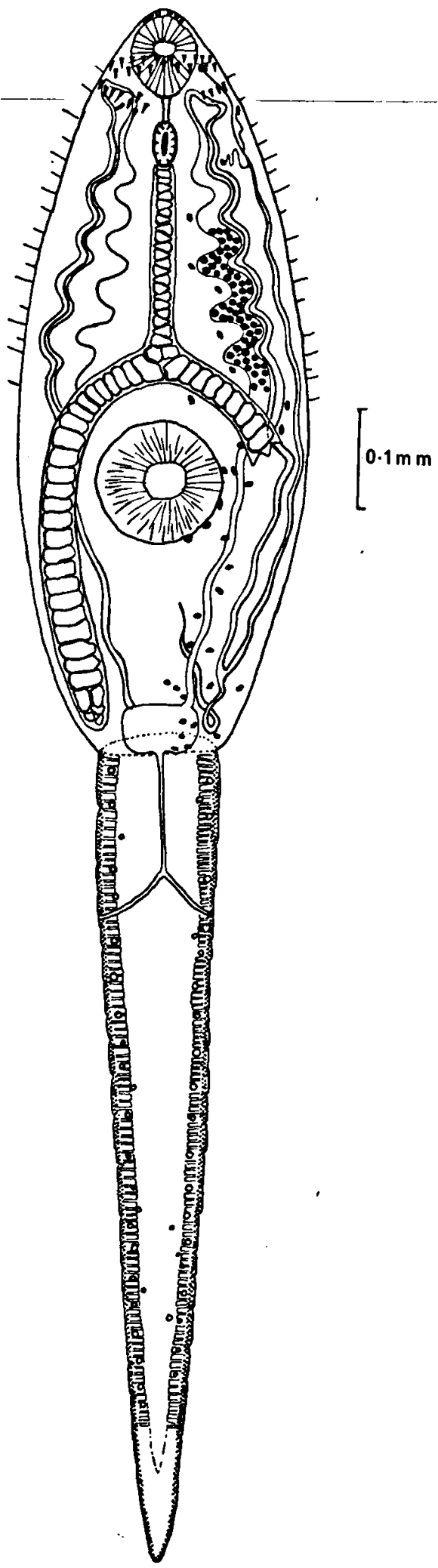

Fig. 1. Cercaria cf. deficipinnata. observations on them are incomplete, they are not mentioned further.

The third echinostome cercaria, found on 18 September 1973, showed close resemblance to $C$. deficipinnata Khan, 1960. Its host was Lymnaea stagnalis.

Description of the cercaria (fig. 1).

Body oval. Cuticle of anterior part of body covered with irregularly arranged small spines, in some specimens confined to region of oral sucker only, in others well up to ventral sucker. The collar bears 37 spines: five corner spines and four lateral ones on each side and a double dorsal row of ten oral and nine aboral spines (formula: $5+4+19+4+5=37$ ). Tail without fin fold.

Prepharynx short. Oesophagus and caeca consisting of one row of cells. The region around the ventral sucker contains many cystogenous cells, which obscure other structures. Excretory vesicle simple, rectangular. The small excretory tubes could not be traced but the position of the flame cells is shown in fig. 1. There are 35 flame cells on each side and 14-21 "Treibflammen" in each collecting vessel.

No details can be given of the internal structure of the redia, as only formalin material was available. The metacercaria was experimentally obtained from Lymnaea peregra.

Dimensions were taken from 20 cercariae, 10 rediae and 10 metacercariae and compared with those given by Khan (1960), see table III.

Our specimens differed from Khan's (1960) description in the following characters:

1. Dimensions. Khan's specimens are smaller, which might partly be attributed to his fixation method.

2. Construction of oesophagus and caeca. According to Khan, each compartment consists of three cells, whereas in our specimens there was but one. When observing specimens for some time under a cover glass, we noticed these cells splitting up into fragments.

3. The pattern of the collar spines in Khan's specimens is not made clear. If his figure is correct, there is but a single dorsal row of spines, which is highly improbable.

4. The distribution pattern of the flame cells given in Khan's figure is different from ours, although he, too, found 35 flame cells on each side.

We are not able to judge the importance of 
Table III. Measurements (in $\mu \mathrm{m}$ ) of Cercaria cf. deficipinnata, its redia and metacercarial cyst.

\begin{tabular}{|c|c|c|c|c|}
\hline & & $\begin{array}{l}\text { Khan (1960) } \\
\text { (fixed) }\end{array}$ & $\begin{array}{l}\text { present } \\
\text { average }\end{array}$ & $\begin{array}{l}\text { naterial (heat-killed) } \\
\text { range }\end{array}$ \\
\hline Cercaria & & & & \\
\hline Body & length & $580-620$ & 749 & $702-805$ \\
\hline & width & $220-240$ & 278 & $207-345$ \\
\hline Tail & length & $756-800$ & 817 & $690-932$ \\
\hline & width & $83-90$ & 118 & $92-150$ \\
\hline Oral sucker & length & $53-56$ & 73 & $53-90$ \\
\hline Pharynx & length & $30-33$ & 41 & $32-48$ \\
\hline Ventral sucker & diam. & $80-100 \times 90-110$ & $120 \times 133$ & $93-146 \times 106-173$ \\
\hline Corner spine & length & 40 & 42 & \\
\hline Dorsal spine & length & 33 & 29 & \\
\hline Redia (fixed) & & & & \\
\hline Body & length & $1500-2400$ & 2790 & \\
\hline & width & $360-495$ & 285 & \\
\hline Pharynx & length & & 103 & \\
\hline Cyst & & & & \\
\hline External diameter & & $240-263$ & 286 & \\
\hline Thickness of wall & & 13 & 10.5 & \\
\hline
\end{tabular}

these differences between our specimens and Khan's. We do not feel justified, however, to attribute our specimens to a new species.

\section{Cercaria helvetica II Dubois, 1929}

Syn.: Cercaria Z Rees, 1932.

We found this echinostome cercaria in three samples taken in the Bijlmermeer ditch. It has also been described by Meyer (1964) who considered the form found by Rees synonymous with C. helvetica II, with which we agree.

The collar spine pattern was studied in the metacercaria. We found four corner spines on both sides, and five lateral spines. The remaining spines are arranged in two rows, the aboral row containing 13 spines. The formula is: $4+5+27$ $+5+4=45$. On each side 24 flame cells were found, as well as 10-14 "Treibflammen". Hosts were Lymnaea peregra and $L$. stagnalis.

Honer (1963) also reported having seen this species, but as his specimens had 50 or more collar spines, he was apparently mistaken.

Cercaria of Hypoderaeum conoideum (Bloch, 1782)

This species has been found fairly often in the vicinity of Amsterdam (unpublished reports of Borgsteede, Daalder and others). It occurred in two samples from the Bijlmermeer. In both cases the host was Lymnaea peregra.
The species is easily recognized by the presence of 49 collar spines, 5 of which on each side are corner spines. Our specimens agreed with the descriptions by Dubois (1929) and Meyer (1964). We observed 24 flame cells on each side of the body, a formula could not be determined.

\section{Cercaria helvetica XIX Dubois, 1929}

Syn.: C. cystogenata Probert, 1965?

In the Diemerplassen, a psilostome cercaria was found on 28 May 1973 and 1 July 1974 showing much resemblance to $C$. helvetica $X I X$ and also to a form described by Probert (1965) from Wales. The host was Bithynia tentaculata. In Probert's opinion, his $C$. cystogenata differs from $C$. helvetica $X I X$ in details of body setae and shape of the excretory vesicle. But Dubois (1929) has not paid attention to setae in any of his cercariae, and his description of the vesicle is generally rather sketchy. We are therefore inclined to stress the similarity between both these forms and the one found by us, rather than the differences. A comparison of dimensions is omitted here, because we could measure two specimens only. The values we got are within the range given by Dubois and Probert.

In general appearance and behaviour this cercaria is very much like an echinostome cercaria without a collar. The body is covered by a thick cuticle bearing no spines or scales; hairs were not observed. The suckers are powerful, the 
ventral one which is situated just behind the middle of the body is slightly the larger. There are two small caudal pockets at the tail base on the ventral side. The tail bears no fin fold.

Oral opening subterminal, followed by a short prepharynx, a pharynx and a rather short oesophagus. Division of intestine well before ventral sucker, the caeca extend to the anterior edge of the excretory vesicle. Dark gland cells filled with rod-like substances are situated extracaecally and inhibit the observation of the flame cells. The collecting ducts of the excretory system contain 14-20 coarse granula each. The excretory vesicle is V-shaped with a minute separate posterior part in the tail base. The caudal duct bifurcates and opens at about half the tail length.

At room temperature, these cercariae survived for about 24 hours. Probert found metacercariae of his C. cystogenata on the inside of shells of pulmonate snails. We had only Bithynia available which were immediately located by the cercariae. We have observed them swimming towards a snail, shedding their tails and often disappearing into the shell. The metacercariae have not been studied by us.

Under a cover glass the cercariae were very mobile. Frequently they bent their bodies in a circle, pushing the oral part into the ventral sucker.

The rediae were somewhat smaller than those found by both Dubois and Probert, their body length being $550 \mu \mathrm{m}$, pharynx length $75 \mu \mathrm{m}$ and the intestine length being over half the body length (means of five specimens).

\section{Cercaria imbricata Looss, 1893, nec Looss, 1896}

This is the cercaria of Notocotylus imbricatus (Looss, 1893), a parasite of ducks. It is therefore not surprising that this cercaria can be found frequently in the area under investigation. As it is the only monostome species known to occur in Bithynia tentaculata it is easily identified.

It was found twice in the Bijlmermeer and regularly in the Diemerplassen, as early as the end of April. In the province of North-Holland, it has also been found by Honer (1963) and by several students of our laboratory.

The morphology of our cercaria is in agreement with that described by Pike (1969).

When in a drop of water under the micro-

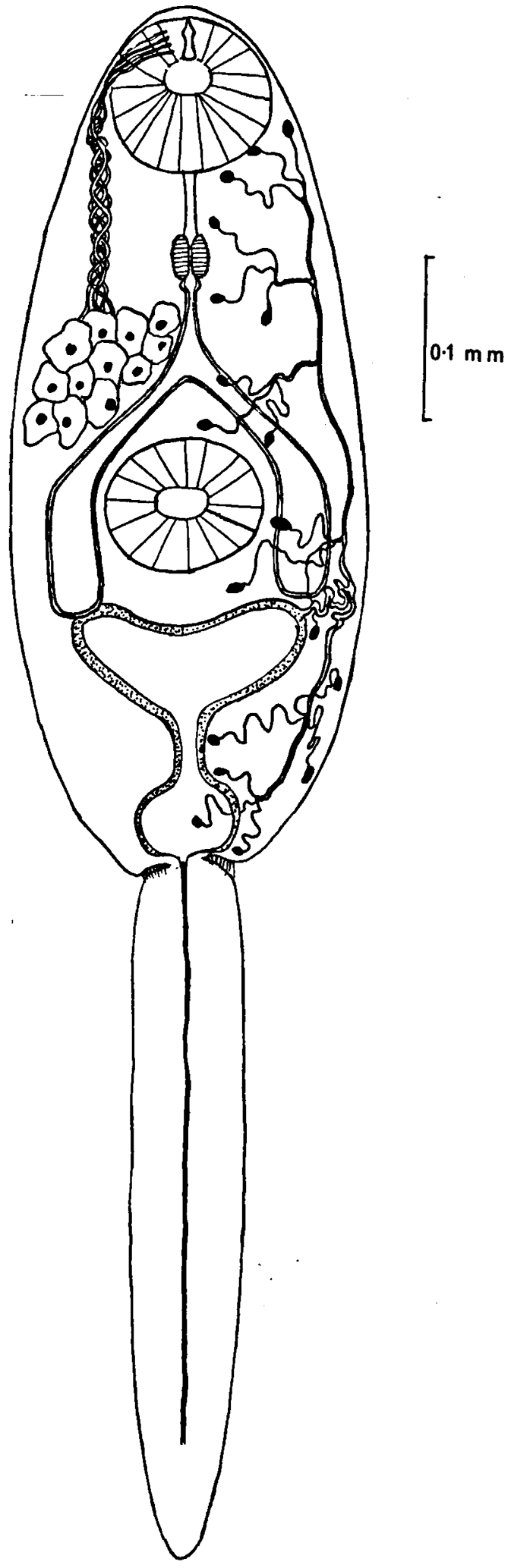

Fig. 2. Cercaria otiosa n. sp. 
scope, $C$. imbricata was observed to spend about 30 minutes swimming intermittently before encystment. Encystment occurred sooner when the water evaporated rather quickly. Curious "searching movements" were noticed during swimming: successively, a cercaria was observed remaining fixed on a certain place (usually on the margin of the drop), dartling away after a few seconds, returning to exactly the same spot and leaving it again. In the laboratory, encystment readily occurred on the walls of glass tubes and on slides.

\section{Cercaria otiosa n. sp.}

(Fig. 2)

In three sampling points of the Bijlmermeer ditch, on 31 July and 18 and 27 September 1973, a species of xiphidiocercariae was found that could not be identified with any of the described forms. The host was Lymnaea peregra.

Description of the cercaria (fig. 2).

Body oval. Cuticle smooth, without spines or setae. Caudal pockets with 16 spines each, 8 pointing dorsally and 8 ventrally, which are all observed only when the animal is completely flattened. Oral sucker larger than the ventral one, which lies behind midline of body. Prepharynx present; pharynx oval; oesophagus rather short and widening gradually. Caeca rather wide, ending very near anterior margin of excretory vesicle.

There are 12 penetration glands on each side in a bunch anterolateral to the ventral sucker; 4 penetration ducts run forward from each bunch and terminate at the sides of the stylet. The stylet is small and rather slender.

The excretory system was studied in a $0.7 \%$ $\mathrm{NaCl}$ solution, because a higher $\mathrm{NaCl}$ concen-

Table IV. Measurements (in $\mu \mathrm{m}$ ) of Cercaria otiosa $\mathrm{n} . \mathrm{sp}$.

\begin{tabular}{llrr} 
& & average & range \\
\hline Body & length & 521 & $495-575$ \\
& width & 216 & $165-261$ \\
Tail & length & 412 & $380-460$ \\
& width & 63 & $48-74$ \\
Oral sucker & length & 101 & $88-117$ \\
Ventral sucker & length & 91 & $77-106$ \\
Pharynx & length & 29 & $21-35$ \\
Stylet & length & 22 & $19-24$ \\
\multicolumn{2}{l}{ Distance apex - centre } \\
of ventral sucker & max. width & 5.2 & $4.8-5.5$ \\
\hline
\end{tabular}

tration had a damaging effect on the cercariae. The excretory vesicle is thick-walled, large and clearly visible.

Flame cell formula: $2[(3+3+3)+(3+3+3)]=$ 36.

The dimensions (table IV) were influenced by the age of the cercariae. In freshly emerged specimens the body was somewhat shorter and the tail longer than in cercariae older than 24 hours.

The sporocyst has not been studied.

The cercariae emerged throughout the day. In the laboratory they were not very active: after emergence they sunk to the bottom of the vessel and remained there. Activity (swimming, creeping) could be stimulated for a short time by shaking the vessel.

Grabda-Kazubska (1971) has given a survey of the group "armatae" of xiphidiocercariae, to which the present species clearly belongs. In this group she has distinguished four types, and according to her definition our species belongs to the Opisthioglyphe type. Of the cercariae attributed to this type, only that of Haplometra cylindracea, which is much smaller than our species, is known to have 12 pairs of penetration glands. The forms with similar dimensions, as far as we could trace them in the literature, have a different number of penetration glands or a different behaviour pattern. Many species of Grabda-Kazubska's Opisthioglyphe type are said to penetrate into Amphibia. In recent years the study of parasites of Amphibia has become intensified, also in The Netherlands. We therefore present this description of a new cercaria in the expectation that it might be found again during the study of a trematode life cycle in Amphibia.

\section{Cercariaeum paludinae impurae Filippi, 1854}

This cercaria is regularly found in Bithynia tentaculata in the Diemerplassen. In 1966, Borgsteede (pers. comm.) was the first to find it in The Netherlands. The Tench, Tinca tinca (Linnaeus, 1758), is the final host of this parasite. Its life cycle has been studied in our laboratory, a detailed description will be published elsewhere.

\section{Cercaria lophocerca Filippi, 1857}

The cercaria was occasionally found in the Diemerplassen, in Bithynia tentaculata, in early 
summer viz. on 15 May 1973, 1 July 1974 and 24 June 1975. The species has been found in 1967 in The Netherlands by Daalder (pers. comm.) and there are various descriptions of it, among others by Meyer (1964) and Probert (1965). The cercariae are very inconspicuous, an infection is therefore not noted before the snail host is opened. Within the snail many juvenile cercariae can be found. Wesenberg-Lund (1934) remarked that most of the specimens studied by him are probably not yet "ripe". We could not observe many details of the morphology and we discerned only an "Anlage" of the ventral sucker. Meyer (1964) supposes that $C$. lophocerca is probably a collective term for larvae of various opisthorchid species. In view of this, the measurements obtained by us are presented in table $\mathrm{V}$.

Table V. Measurements (in $\mu \mathrm{m}$ ) of Cercaria lophocerca.

\begin{tabular}{|c|c|c|c|}
\hline & & $\begin{array}{l}\text { Meyer } \\
(1964)\end{array}$ & $\begin{array}{l}\text { present material } \\
\text { (2 specimens) }\end{array}$ \\
\hline \multirow[t]{2}{*}{ Body } & length & 204 & 218 \\
\hline & width & 103 & 109 \\
\hline Tail & length & 409 & \\
\hline Oral sucker & length & 39 & 36 \\
\hline Anlage ventral sucker & $\begin{array}{l}\text { length } \\
\text { width }\end{array}$ & 29 & 31 \\
\hline $\begin{array}{l}\text { Distance apex } \\
\text { - eyespots } \\
\text { Distance apex } \\
\text { - centre of ventral } \\
\text { sucker }\end{array}$ & & 62 & 63 \\
\hline
\end{tabular}

\section{DISCUSSION}

As already stated, the two sampling areas under study differed very much in character. Although no exact data on infection percentages can be given, we have the impression that infection in the small Bijlmermeer ditches was much more intense than in the larger Diemerplassen. This phenomenon is well known and has already been discussed by Ginecinskaja (1971) and other authors.

The gastropod fauna in the two areas was quite different. In the ditches lymnaeids were abundant, along the lake Bithynia tentaculata was the dominating species. Lymnaeids (Pulmonata) are good hosts of furco- and echinostome cercariae, which groups are only occasionally present in Bithynia (Prosobranchia) species. Generally speaking, the pulmonate and the prosobranchiate snails each have their characteristic trematode fauna.

It is easily understood that the trematodes found in both areas have final hosts that are common in and around Amsterdam, such as ducks and Black-headed Gulls (Diplostomum spathaceum, Cercaria helvetica XV, Notocotylus imbricatus).

Of the species found in the Bijlmermeer only, Apatemon minor and Hypoderaeum conoideum are also parasites of ducks and might be expected to occur in the Diemerplassen as well. The hosts of the echinostomes Cercaria helvetica $I I$ and $C$. deficipinnata should, anyway, be homoiothermic but are not known. The host of the new xiphidiocercaria might be a toad or frog, and these are more likely to occur in shallow ditches than in a larger, open water body such as the Diemerplassen, where frogs have been observed only occasionally.

Unlike the Bijlmermeer ditches, the Overdiemerplas in particular is known as a rich fishing water, which circumstance is reflected in the presence of various larvae of trematodes that are specific either of fish (C. cristata and $C$. paludinae impurae) or of fish-eating birds or mammals ( $C$. lophocerca and the cercaria of Paryphostomum radiatum).

About the interesting species $C$. helvetica $X I X$ nothing can be said because its life cycle is not yet known.

\section{REFERENCES}

Dubots, G., 1929. Les cercaires de la région de Neuchâtel. Bull. Soc. neuchâtel. Sci. nat., 53: 1-177.

GinecinsKaja, T. A., 1971. Okologische Beziehungen zwischen den Trematoden und den Mollusken. Parasit. SchrReihe, 21: 105-109.

GrABDA-KAZUBSKA, B., 1971. Main morphological characters in xiphidiocercariae armatae Lühe, 1909 and their taxonomic importance. Parasit. SchrReihe, 21: 49-55.

Honer, M. R., 1963. Freshwater larval trematodes in the Netherlands: a synecological study of their occurrence: 1-116 (Thesis, University of Utrecht; Elinkwijk, Utrecht).

ILES, Сн., 1959. The larval trematodes of certain fresh-water molluscs. I. The furcocercariae. Parasitology, 49: $478-504$.

Кнал, D., 1960. Studies on larval trematodes infecting freshwater snails in London (U.K.) and some adjoining areas. $I$. Echinostome cercariae. J. Helminth., 34: 277-304.

KiselienE, V., 1971. The life cycle of Paryphostomum radiatum (Dujardin, 1845) Dietz, 1909 (Echinostomatidae). Parasit. SchrReihe, 21: 161-164. 
Meyer, P. O., 1964. Die Trematodenlarven aus dem Gebiete von Zürich. Vjschr. naturf. Ges. Zürich, 109: 277-372 (Thesis, University of Zürich).

NAsiR, P. \& D. A. Erasmus, 1964. A key to the cercariae from British freshwater molluscs. J. Helminth., 38: 245-268.

Pike, A. W., 1969. Observations on the life-cycles of Notocotylus triserialis Diesing, 1839 and N. imbricatus (Looss, 1893) sensu Szidat, 1935. J. Helminth., 43: 145-165.
Probert, A. J., 1965. Studies on larval trematodes infecting the fresh water molluscs of Llangorse Lake, South Wales. II. The gymnocephalous cercariae. J. Helminth., 39: $53-66$.

Wesenberg-Lund, C., 1934. Contributions to the development of the Trematoda Digenea. II. The biology of the freshwater cercariae in Danish freshwaters. K. dansk. Vidensk. Selsk. Skr., naturv. og math., Afd. 9, Raekke V, 3: $1-223$.

Received: 1 June 1976 